\title{
Policy to Eradicate Crime Funding of Terrorism as Transnational Organized Crime
}

\author{
Ardken Fisabillah ${ }^{1}$, Pujiyono ${ }^{2}$, Umi Rozah ${ }^{3}$ \\ \{afisabillah97@gmail.com ${ }^{1 *}$, pujiyono@live.undip.ac.id ${ }^{2}$, umi.rozah@live.undip.ac.id ${ }^{3}$ \}
}

Fakultas Hukum, Universitas Diponegoro, Jl. Prof. H. Soedarto, S.H., Semarang, Indonesia $50275^{1,2,3}$

\begin{abstract}
One type of crime that occurs in the community is terrorism funding. The funding of terrorism in Indonesia has expanded and spread to various elements of society. Terrorism funding that promises considerable material rewards makes many people want to commit acts of terrorism without knowing a clear cause and effect. Terrorism funding is the way that foreign terrorists recruit new members in Indonesia. The issue of financing terrorism has also become a problem in various countries including the ASEAN Region, which is no exception to Indonesia. This study aims to determine and analyze criminal law policies in eradicating funding of terrorism as a transnational organized crime in positive law, also, in knowing and analyzing criminal acts of financing terrorism as a transnational organized crime in the future.
\end{abstract}

Keywords: Policy, Criminal Funding of Terrorism, Indonesian Criminal Law, Transnational Organized Crime.

\section{Introduction}

Terrorism is part of a crime that cannot be classified as an ordinary crime. Academically, terrorism is categorized as an extraordinary crime and categorized as crime against humanity.. At the juridical level, terrorism is a crime against state security in view of such categories, so eradication is certainly not able to use the usual methods as handling ordinary crime such as theft, murder or persecution. The crime of terrorism is a form of action that threatens the security and sovereignty of the Unitary Republic of Indonesia (NKRI).

Terrorism is not really a new phenomenon because it has existed since the 19th century in the international political arena. In general it is closely related to the domestic stability of a country. However, today, terrorism has broad dimensions related to various aspects of life and transcending national boundaries. Terrorism no longer only targets political life as it first appeared, but also has penetrated and damaged and destroyed the joints of human life, such as declining economic activity and disturbed humanitarianism and civilized culture of society so that it is classified as one of the eight transnational crimes.

Terrorism is a crime against humanity and a crime against civilization that is a threat to all nations and enemies of all religions in this world. Terrorism in its development has built an organization and has a global network where terrorist groups operating in various countries have been co-opted by an international terrorism network and have relationships and mechanisms of cooperation with each other both in the operational aspects of infrastructure and supporting infrastructure. 
Based on paragraph IV of the Preamble of the 1945 Constitution of the Republic of Indonesia, one of the objectives of the establishment of the Republic of Indonesia is to protect all Indonesians and all Indonesian blood. One form of implementing this national goal is to protect all Indonesians from the threat of terrorism. The criminal act of terrorism is an international crime that endangers world security and peace and is a grave violation of human rights, especially the right to life. The series of criminal acts of terrorism that occurred in the territory of the Unitary State of the Republic of Indonesia have resulted in loss of life regardless of victims, widespread public fear, and loss of property that has a wide-ranging impact on social life, economic, political, and international relations. For example, the impact of the Bali bombing tragedy in October 2002 reduced local economic activity throughout 2003 by reducing the income of Balinese residents by around 43 percent, partly due to layoffs with 29 percent of the workforce in Bali. The Bali tragedy also affected the national economy among others by decreasing the flow of foreign tourists (tourists) by 30 percent. In a high intensity and continuously, terrorism can threaten the life of the nation and state.

In Indonesia, the claim that terrorism is a real threat, only surfaced after 11 September 2001, precisely since the tragedy of Legian Bali on October 12, 2002. Although previously Indonesia has experienced a number of incidents even more than 25 incidents of terrorism since the hijacking of the Garuda Woyla aircraft, the blasting of Borobudur Temple, and The BCA building in 1984 and 1985, with perpetrators of Indonesian citizens, was followed by a number of explosions in a number of Indonesian regions. As a country with the largest Muslim population in the world, there are groups that base themselves on the struggle of certain groups known as radical Islam. This group has the goal of the struggle to build an Islamic state that applies Islamic law purely in state law. This goal usually arises because of dissatisfaction with government policies that are considered too secular and dictated by many Western countries to marginalize Muslim Fundamentalists. The marginalization covers at least the political and economic aspects.

Politically, in the past the New Order government distanced itself from radical Muslim groups because of the trauma of the DI/TII rebellion. In addition, radical Muslim groups receive very strict supervision in every activity from government officials. At the same time the launching of a single ideology, namely Pancasila by the government, was met with stiff resistance from terrorist groups, which resulted in repressive actions from the security apparatuses.

In general, terrorist funding comes from two main sources. that is, financial support provided by organizations that collect and make these funds available to terrorists or terrorist organizations. A person with sufficient finance can also provide substantial funding for terrorist groups. The second source of terrorist funding or terrorist organizations is income generated directly from several activities that generate funds. Such funding can come from crime or other illegal activities. A terrorist group in a certain region can finance itself for example through kidnapping, extortion, tax evasion, fraud, robbery, narcotics trafficking, and other criminal activities.

Requests and collection of funds from the public is one way to obtain funds to support terrorism activities. Often the fundraising is carried out on behalf of organizations that already have status as charitable organizations or aid agencies, or organizations aimed at specific communities. Most of its members do not have adequate knowledge about the use of donated funds. For example, supporters of terrorist activities in one country have legitimate activities in other countries to maintain sources of financial funds. Supporters of these activities get funding by infiltrating and taking over an institution whose members are immigrant communities where the organization originated. Some methods of collecting funds include 
withdrawing funds from each member, selling goods, cultural attractions, social activities, door-to-door socialization among the community and donations from members who are classified as capable in the community. Funding for terrorist groups can also involve income derived from legal sources or from a combination of legal and illegitimate sources. The extent to which the role of legitimate funds in supporting terrorism varies depends on terrorist groups and the geographical location where terrorist activities are carried out. From a technical point of view, the methods used by terrorists and their organizations to obtain funds from illegal activities are not much different from the methods used by conservative criminal organizations.

In collecting funds, terrorists work in an organized manner, both in small and large groups by distributing tasks to each of their members and making it easier to raise funds. There are two forms of collecting terrorist funds, namely legal and illegal. Legal activities are carried out in the form of activities such as contributions from members of the terror network and sympathizers both at home and abroad. Illegal activities are carried out with criminal acts such as robbery of banks and government-owned financial institutions, gold shops, non-Muslim entrepreneurs, ITE/cyber crimes and money laundering by conducting business that appears to be legal.

Terrorists began to enter the banking sector by using pseudonyms to hide their real identities and the purpose of using funds in accounts. The most appropriate way to overcome the entry of terrorists into the banking system is by freezing terrorist assets and assets, as stated in the FATF special recommendation. Currently there are 17 Indonesian citizens registered in UNSC 1267, with three of them successfully frozen, namely Encep Nurjaman alias Hambali, Zulkarnaen, and Umar Patek.

When terrorists or terrorist organizations obtain their funds from legitimate activities (such as donations), what terrorists or terrorist organizations do is to disguise the relationship between these legitimate activities and terrorist activities carried out. This makes financing of terrorism difficult to detect or trace. Another important aspect that makes financing terrorism difficult to detect is the size and nature of the transaction. Funding used to increase terrorism activities does not always relate to large amounts of money, and transactions that are carried out are not complex, and can even involve humanitarian funds (for example subsistence assistance).

1. How is the policy to eradicate the crime of financing terrorism as a transnational organized crime in the perspective of criminal law in Indonesia?

2. What is the concept of preventing the crime of financing terrorism as a transnational organized crime in the future?1. How is the policy to eradicate the crime of financing terrorism as a transnational organized crime in the perspective of criminal law in Indonesia? 2. What is the concept of preventing the crime of financing terrorism as a transnational organized crime in the future?

\section{Method}

The approach used is a normative juridical method. The specifications of this study are descriptive.

Secondary data used in this study can be divided into 3 (three), namely: Primary legal materials, secondary legal materials, and tertiary legal materials. 


\section{Results and Discussion}

\subsection{Policy to Eradicate Crime Funding of Terrorism as Transnational Organized Crime in Perspective of Criminal Law in Indonesia}

Indonesia places ASEAN as an important part in collaborating efforts to tackle terrorism. This is done because terrorism in Indonesia is believed to have an international network, including in several ASEAN countries. The Bali Bombing incident involving a terrorist network from Malaysia strengthened this belief. The importance of cooperation agreements between ASEAN countries was conveyed in Indonesian President Megawati's speech at the 36th ASEAN anniversary in Jakarta in 2003:[1]

"Regional plans of action to tackle such problems had long been established as part and parcel of ASEAN's functional cooperation, but suddenly these appeared to be inadequate in the face of the cataclysms like terrorist attacks in the United States and in Bali. These two tragedies roused the entire civilized world to the immense danger of international terrorism and other transnational crimes. It became clear that no single country or group of countries could overcome this threat alone. In Indonesia's view, which is shared by the rest of the ASEAN members, it would take a global coalition involving all nations, all societies, religions and cultures to defeat this threat."

Indonesia has a comprehensive strategy in handling terrorism funding that combines hard and soft approaches. In dealing with hard approach, Indonesia has issued Law No. 15 of 2003 concerning the Stipulation of Regulations governing the Substitute for Law Number 1 of 2001 concerning Eradication of the Criminal Acts of Terrorism,[2] which was then carried out to change with Law No. 5 of 2018 concerning Amendments to Law No.15 of 2003 concerning the Stipulation of Government Regulations in Lieu of Law Number 1 of 2001 concerning Eradication of Terrorism Criminal Acts (Law on Terrorism) and Law Number 9 of 2013 concerning Prevention and Eradication of Acts of Terrorism Criminal Funding for Terrorism.[3] Furthermore, in the context of strengthening efforts to counter terrorism funding, Indonesia has also ratified the Joint Regulation on the Inclusion of Identity of Persons and Corporations in the List of Suspected Terrorists and Terrorist Organizations and the Blocking of bank account accounts as well as on the Funds belonging to People or Corporations that are Listed in the List of Suspected Terrorists and Terrorist Organizations.[1]

It is noteworthy that in the new Terrorism Law, there is the addition of many regulatory substances to strengthen the existing arrangements in Law No. 15 of 2003, including:[1]

1. New criminalization of various new formulas of acts of terrorism, such as types of explosives, following military or paramilitary training or other exercises both domestically and abroad with the intention of committing criminal acts of terrorism;

2. The imposition of sanctions against perpetrators of criminal acts of good consensus, preparation, trial and assistance to commit criminal acts of terrorism;

3. Expansion of criminal acts on founders, leaders of corporate activities against corporations that are imposed on the founders of management, or people who direct additional criminal activities in the form of revocation of the right to passport within a certain period of time;

4. Decisions on criminal proceedings such as the addition of arrest, detention and extension of arrest and detention for the benefit of investigators and public 
prosecutors as well as examination of cases of criminal acts of terrorism by public prosecutors;

5. Protection of criminal acts as a form of state responsibility;

6. Prevention of criminal acts of terrorism carried out by related agencies In accordance with the respective functions and authorities coordinated by BNPT; and

7. Institutional BNPT and its oversight and the role of the TNI.

In addition, there is a strategic fundamental formulation of the results of the input of various members of the Special Committee with the government Committee. If further described, the substance includes the following substances:[1]

1. Define clearly what actually terrorism is, so that the scope of terrorism crimes can be clearly identified so that the criminal act of terrorism is not identified with sensitive matters in the form of sentiments towards certain groups or groups with some aspects of the crime;

2. Eradicate criminal sanctions to revoke citizenship status. According to the universal declaration of human right 1948 , it is the right of every person to citizenship and no one can be revoked arbitrarily or denied the right to change his citizenship;

3. Remove the article known by the community as Guantanamo article which places a person as suspected of terrorism in a certain place or location that cannot be known by the public;

4. Add comprehensive provisions regarding the protection of victims of terrorism crime starting from the definition of the victim, the scope of the victim, the granting of the victims' rights which was originally in Law 15 of 2003 only regulates compensation for restitution, whereas in the Act of Terrorism the Criminal Act has governed granting rights in the form of medical assistance, psychological rehabilitation, psychosocial rehabilitation, compensation for victims who died, the provision of restitution and compensation;

5. Arrange the granting of rights to victims who suffered before the Terrorism Act was passed. This means that for the victims since the first Bali bombing, the bombing of Thamrin;

6. Add prevention provisions. In this context, prevention consists of national preparedness for counter-radicalization and deradicalization;

7. Include provisions that victims of terrorism are the responsibility of the state;

8. include the duties, functions and authorities of the BNPT

9. Add provisions regarding supervision;

10. Add to the provisions for the involvement of the TNI which in the case of its implementation will be regulated in a presidential regulation within the time of its formation a maximum of 1 year after this Law is passed;

11. Amend the provisions on political crimes in article 5, which stipulates that criminal acts of terrorism are excluded from political crimes that cannot be extradited. This is in accordance with Law Number 5 of 2006 concerning Ratification of the International Convention on Combating Bombings by Terrorists; Add articles that provide sanctions against state officials who abuse the power.

In addition to making changes to the Law on Terrorism Funding, Indonesia also supports prevention efforts including implementing the UN Security Council Resolutions 1267 (1999) and 1988 (2011) which are in line with Indonesia's national law related to Combating terrorism financing. On that basis, Indonesia already has a List of Suspected Terrorists and 
Terrorist Organizations, and a flow of terrorism funds based on a list of Al-Qaeda Sanctions and a List of Taliban for the freezing process transnational extraordinary crimes and crossing national borders. Therefore, the actions taken by the government are carried out both preventive (preventive) and repressive (responsive).[4]

\subsection{Concept of Criminal Prevention of Terrorism Funding as a Transnational Organized Crime in the Future}

Other cooperation through the ASEAN Convention on Counter Terrorism (ACCT) is one of the achievements of the special ASEAN cooperation in the field of combating terrorism. ACCT was signed at the 12th ASEAN Summit in Cebu, Philippines on January 13, 2007. This convention provides a strong legal basis for enhancing ASEAN cooperation in the area of combating terrorism and financing terrorism. Besides having a regional character, ACCT has a comprehensive scope that covers aspects of prevention, enforcement, in the rehabilitation program so that it has added value when compared to similar conventions. In addition, the convention includes various collaborative cooperation in the field of handling the root causes of terrorism including, cooperation to encourage interfaith dialogues which are ideas and thoughts for Indonesia that have been adopted globally. [4]

ACCT is expected to provide added value compared to international legal instruments similar to designs that have strong regional characteristics. As stipulated in the ACCT, this convention shall take effect 30 days after ASEAN Member States submit the six instruments of ratification to the Secretary General of ASEAN. Indonesia itself ratified ACCT through Law No. 5 of 2012 which was ratified on April 9, 2012. In 2013, all ASEAN countries have ratified the ACCT marked by the submission of instruments of ratification by Laos and Malaysia to the ASEAN Secretariat in January 2013. With the signing of the ACCT by all ASEAN member countries, ASEAN has taken other steps in fulfilling the ASEAN Security and Political Blueprint, as well as in efforts to develop the ASEAN region by creating a safer situation for everyone.[4]

Cooperation carried out by governments in the region is flexible in nature, tailored to their individual needs. to always be the same. This happens due to many things, and one of them is because each ASEAN member country has a different perception, but the regional countries have the same goal as tackling terrorism funding comprehensively. As a concrete step, cooperation in a bilateral perspective is also carried out. An example is the formation of a memorandum of understanding between Indonesia and the Philippines to establish a framework for dealing with security disturbances and crime between the two countries. This memorandum of understanding will provide a framework for cooperation in preventing, suppressing, combating international terrorism and transnational crime.[4]

The post-retreat commitment of the ASEAN Defense Ministers (ASEAN Defense Ministers' Meeting/ADMM) in Singapore on February 6, 2018 stated that the crime of financing terrorism was considered the most serious security threat. In addition, ASEAN defense ministers are very concerned about the rise of terrorism in the region carried out by individuals and groups that are increasingly sophisticated with tactics and deadly weapons. The ASEAN Defense Ministers also stated the scale and complexity of the threat of terrorism in the region continues to grow due to the flow of foreign fighters and cross-border terrorists. That is why, ASEAN defense ministers agreed to increase counterterrorism to improve ASEAN resilience against terrorist funding, work together to respond to ongoing threats, and ensure recovery from terror attacks.[4] Through the efforts of the Defense Ministers in this region, ASEAN will increase practical cooperation through joint exercises and training, 
sharing information, increasing dialogue and various practical experiences, and fighting terrorist propaganda through disseminating positive messages about respect, inclusive and moderation.[4]

The same regional cheer is considered effective in tackling terrorism funding. The Government of Indonesia and the five ASEAN countries agreed to work together on the exchange of strategic information through "Our Eyes" to counter the threat of financing terrorism and radicalism. Cooperation aims to ward off and also deal with all acts of terrorism and radicalism together so that these crimes do not spread and cause anxiety and fear among citizens of a number of countries. The mechanism adopted is that participating countries can exchange strategic information that can be used to help improve operations against funding of terrorism and radicalism.[5]

The five countries that agreed were Malaysia, the Philippines, Thailand, Singapore and Brunei Darussalam. Each of these countries has a different way of dealing with the threat of terrorism. Therefore, synergy and coordination are needed in order to obtain strategic information. Like the concept of "Five Eyes" by the United States and its allies, the cooperation involves elements of defense or military collaborations and integrated intelligence networks that can be carried out in which participant countries can exchange strategic information, which can be used to help improve operations against funding of terrorism and radicalism.[5]

\section{Conclusion}

The eradication of the crime of financing terrorism in Indonesia is done in 2 ways, namely soft approach and hard approach. In relation to the soft approach, Indonesia carries out a program of de-radicalization and counter-radicalization. The de-radicalization approach is a counterweight to the law enforcement approach using the criminal law tool for overcoming crime with a penal approach. While the hard approach is to issue laws and ratify international treaties that Indonesia is involved in and addressed to, which forms the legal basis for the Indonesian National Counterterrorism Agency (BNPT), the Indonesian National Armed Forces (TNI), and the Indonesian National Police (POLRI) for eradicate terrorism funding.

The crime of financing terrorism is a transnational crime that is difficult to handle by one country. Therefore, it requires regional cooperation in order to build regional security in the Southeast Asian region. ASEAN has a set of counter-terrorism policies that have been ratified at different times by its members as a form of regional policy harmonization. Although ASEAN countries have their own authority to establish cooperation between countries outside the region, encouragement will be the same for other ASEAN member countries. Harmonization is the maximum achievement for efforts to tackle regional areas. 


\section{References}

[1] I. Puspitasari, "Indonesia's New Foreign Policy-'Thousand FriendsZero Enemy," IDSA Issue Br., vol. 23, p. 4, 2010.

[2] Law Number 1 of 2001 concerning Eradication of Terrorism Acts (Law on Terrorism). .

[3] Law Number 9 of 2013 concerning Prevention and Eradication of Criminal Acts on Terrorism Funding. .

[4] A. Sudirman, Membangun Keamanan Regional Di Asean Dalam Menanggulangi TerorismeMembangun Keamanan Regional Di Asean Dalam Menanggulangi TerorismeMembangun Keamanan Regional Di Asean Dalam Menanggulangi TerorismeMembangun Keamanan Regional Di Asean Dalam Menanggulangi. Jakarta: Erlangga, 2009.

[5] A. Wahid, Kejahatan Teorisme Perspektif Agama, HAM, dan Hukum. Yogyakarta: Rafika Aditama, 2004. 